\title{
Thematic Opinion \\ Green economy in post COVID-19 scenario: Nepalese perspective
}

\author{
Madan Koirala ${ }^{1, *}$ \\ ${ }^{1}$ Central Department of Environmental Science, Tribhuvan University, Kathmandu, Nepal. \\ ORCID: 0000-0003-1413-3915
}

Received: May 28, 2020; Accepted: June 22, 2020; Published: June 25, 2020

\begin{abstract}
COVID-19 might bring a change in socio-economic order, like some socio-economists have started to use the term Before COVID -19 (BC) and After COVID -19 (AC) time period of human history. Postindustrial revolution era of developmental trend of the world is taking a shift, as futurist professionals have started to debate from their perspective. Nepal, though dependent on remittance as major share of GDP, is basically green economy based from ecosystem perspective as it was under harnessed. Since, "cereals couldn't be grown on the smartboard, neither Artificial Intelligence (AI) chips could be eaten", a paradigm shift is obvious with minimal option. In a juncture of time, Nepalese migrant workers, a major source of revenue contributors are returning back to the country due to COVID-19. An alternative national policy to live within the country being involved in green economy is the major way, to contribute the productivity. Out of the land use types of Nepal, majority of population still engaged in green based economy will be the best direction to adopt. In addition, Nepal as one of the countries worst hit by the impact of climate change, despite having only $0.06 \%$ emission of GHGs out of the global share at 2011 value. The country has adopted low carbon emission economic growth path even before the COVID-19 pandemic outbreak.
\end{abstract}

Keywords: COVID-19; green economy; climate change; GHGs

सारांश: केभिड (१९ ले विश्वके सामाजिक(आर्थिक प्रणालीमा ठुलै परीवर्तन ल्याउन सक्छ भन्ने आधारमा केही सामाजिक अर्थशास्त्रीहरुले इतिहासको मानक इसापूर्व (बि.सी.) र इसा पश्चात् (ए.सी.) लाई पुनस्परिभाषित गर्दे कोभिड संक्रमणपूर्व र कोभिड संक्रमण पश्चातलाई 'बि.सी' र 'ए.सी.' भनी व्याख्या गर्न थालेका छन। औद्योगिकीकरणको युग शुरु भए पश्चात् पहिलो पटक कोभिड(१९ महामारीको कारण विश्व परिवेशनै विकासको वैकल्पिक मार्ग सोच्नुपर्ने अवस्थामा पुगेको कुरामा भविष्यद्रष्टाहरुले छलफल शुरु गरेका छन् । कुल गार्हस्थ उत्पादनमा योगदानको हिसाबले नेपाल विप्रेषणमा आधारित अर्थतन्त्र भए पनि पारिस्थितिकीय प्रणालीगत हिसाबले भने यो हरित अर्थतन्त्रमा सबल रहेको मुलक हो। यद्यपि यसको यथोचित उपयोग भने भएको छैन। 'अन्न उत्पादन जमिनमै हुने, र इलोक्टोनिक बौधिक खुराकले मात्र पेट नभरिने' वास्तविकताको सन्दर्भमा न्यूनतम रोजाइमा आधारित भएर पनि विकल्पमा जानैपछ। प्रवासमा काम गरी राजस्वमा उल्लेखनिय योगदान पुरयाउनुहने हाम्रा नेपाली दिदीबहिनी, दाजुभाइहरु यो महामारीको कारण ठुलो संख्यामा स्वदेश फर्किरहनुभएको सन्दर्भमा हरित अर्थतन्त्र मार्फत वंहाहरुको सहभागिताले उत्पादकत्वमा उल्लेख्य योगदान पुरयाउन सक्छ। भूउपयोगको हिसाबले हेर्दा नेपालको अधिकतम भाग हरित पारिस्थितिकिय प्रणाली प्रधान हुनुको कारण जनसख्याको ठूलो हिस्सा पनि यसैबाट लाभान्वित हुन सक्दछ । साथै नेपाल हरितगृह ग्यास उत्सर्जनको हिसाबले न्यून योगदान गर्ने भएतापनि जलवायु परिवर्तनको प्रभावको दृष्टिले अति प्रभावित मुलुकको अग्रपंक्तिमा पर्ने हुनाले पनि हरित अर्थतन्त्र नेपालको लागि सो प्रभाव सम्बोधन गर्ने उपयुक्त रणनीति बन्न सक्ने देखिन्छ। कोभिड (१९ संक्रमण पुर्व नै नेपालले अवलम्बन गर्दे आएको न्युन(कार्बन उत्सर्जनसंग संमन्धित आर्थिक बृध्दिको मार्गचित्र हरित अर्थतन्त्र अनुकुल राष्ट्य रणनीतिसंग मेल खाएको पुंष्टी हुन आंउछ।

\footnotetext{
* Corresponding author, E-mail: Email: mkoirala@cdes.edu.np , madankoirala@gmail.com , Tel.: +977-9851109938 (C) RECAST/TU
} 


\section{Introduction}

The "This storm will pass. But the choices we make now could change our lives for years to come" Harari (2020). Nepal imposed lockdown to deal with the situation four days later, on March 24, 2020, the remark was published. Statistics shows in rise of the number of infected populations, causalities followed by loss of jobs. United Nations Office WHO and other relevant agencies are coming with predictions that the present population may need to live with the COVID-19. Country Specific Strategic Preparedness and Response Plan prepared in close coordination with WHO is capacitating to face the situation (WHO, 2020).

Similar was the case of Adaptation with impact of Climate Change by UNFCCC in COP 12 (2006). Incorporating the provision to mitigate climate change and help countries adapt to the effects. Agreement on the activities for the next few years under the "Nairobi work programme on Impacts, Vulnerability and Adaptation", Management of the Adaptation Fund under the Kyoto Protocol. (UNFCCC, 2006)

Nepal currently suffers high economic costs due to current climate variability and extreme events. Current climate variability and extreme events lead to major impacts and economic costs in Nepal. The annual direct costs of current climate variability in Nepal, on average are estimated to be equivalent to $1.5 \%$ to $2 \%$ of current GDP/year in 2013 prices. In extreme flood years they can be much higher, rising to $5 \%$ or more. This is a high comparison to international level (IDS-Nepal, PAC and GCAP, 2014). In addition to this, post COVID-19 socioeconomic impact is yet to assess. However, some sporadic projections and trends are under discussion.

In reality, there is no substantial data on the number of Nepalese currently working in labour destination countries since the government has only the data on work-permits issued to the migrant worker which is nearly 6.3 million since April, 2000. Professionals and agencies working on Nepali migratory workers mention it is more than 4.5 million based on the labour desk at International Airport (GoN, 2020). The number swells considering the one using additional port or where visa is not required. Government of Nepal policy and program for 2020/2021, has mentioned that step wise bringing back program is underway to those who are working as migrant workers. It has been mentioned that they will be engaged majorly in the agriculture sector to contribute in the national productivity. Operational modalities are underway by the sectoral agencies of the government (GoN, 2020). Nepal's land use major representing forest $(44.47 \%)$, cropland (21.88), grassland (2.60) (MOFE, 2019) will support to sustain them through green economy.

"Trade and Environment Review 2013: Wake Up Before It's Too Late", UN Commission on Trade and Development (UNCTAD) had forecasted back the years "to switch back to our farming roots" towards small scale organic farming.

\section{State of the art review, challenges, and opportunities}

In simple terms, the green Economy could be understood as Low carbon, resource efficient and socially inclusive economy. Growth in income and employment should be driven by public and private investments, which contributes in reducing carbon emissions and pollution. It Enhances energy and resource efficiency and will help in preventing the loss of biodiversity and ecosystem services (supporting, provisioning, regulating and cultural).

2 . The green economy responds to global economic, social, and financial crises by reallocating natural, social and financial capital into creating benefits for economic development, social equity and environmental conservation (Bina, 2013).

Green economy often understood with Sustainable Development or Sustainability lies in a balance of people, planet with an interface of profit in economic terms. Only efficient and productive economies not enough but required to be fair enough both for people and the planet. It considers large investments-based infrastructure development regime versus traditional economic regime. In green economy: Natural ecosystems are in the center considering agriculture, urban infrastructure, and lifestyle to respond.

In a country like Nepal, natural resources green dominant (forest (44.47\%), cropland (21.88), grassland (2.60), and energy source more on hydro and bio green economy becomes an opportunity, for sustainable economic growth. Post COVID-19 could be a departure point with almost 4 million work force returning to the country, losing the remittance that was the major source contributing to national GDP. Clear vision of the national policies with proper implementation mechanism at local level to respond few questions may help.

Since, a vivid indication that comes from the driving seat of central executive to felt realization of the public, the only way to cope is through "food security." Again, the answer goes to the field or green either through provision of agriculture, forestry, grassland or water bodies. Production to processing of the food and forest stuffs will help to respond the post COVID-19 situation, through right 
based approach in the policies, bringing the knowledge institutions on board.

\section{Role of green economy in nation's economic growth and gross domestic product}

With the COVID-19 Pandemic, it is right time to revisit the national policies to address the situation and orient towards future course of direction. Agriculture sector, engaging above $60 \%$ of the population, in return contribution to GDP $27 \%$ only. Similarly, $44.47 \%$ of land covered by forest, the GDP contribution till 2000 was considered to be shear $4 \%$, whereas in a recent estimation it is $15 \%$ (FAO, 2009). Involvement of population by employment sector totaling government, community, cooperative and private is a greater chunk. Revisit the mismatches of these major sectors, could be wise enough from green economy perspective departure point. Similar, are the sectors given little attention such as energy generation through hydro and alternative sources replacing fossil one. Nature linked tourism, comparative advantage to the country's ecology will add value. A country heading towards urbanization, with a concept of smart cities still has room to be benefitted through waste management and pollution control, a course towards green economy.

Young entrepreneurs working on innovative businesses related areas such as: Renewable energy, Waste management, Sustainable mobility, Urban Infrastructure (Sustainable cities, Green smart cities) in a country like Nepal might be the change agents in the paradigm shift through the use of green economy.

\section{Ways forwards}

Government of Nepal has projected itself in the Global Forum through a regular policy dialogue every two years and has coined the forum as "Sagarmatha Sambad." The first event planned on 2-4 April, 2020 "Climate change, mountains and the future of humanity" had to get postponed, due to the COVID-19 outbreak in the last moment. Out of the four themes identified for the dialogue "Green Economy" was one. Understanding was to learn from those who have championed initiatives for a green economy and seek to learn from their experiences.

Some questions were expected to be figured out of the session such as:

$>$ What could be a road map towards green growth and a green economy for countries like Nepal?
$>$ Can international experiences from countries such as Bhutan, Rwanda and Costa Rica be useful?

$>$ More than the half the population live in urban areas and cities tend to be the engines of growth; how can cities drive green growth?

$>$ Will strict codes for green infrastructure with strong enforcement help?

Adopting "green economy" as strategic path could be the way forward to respond the post COVID-19 situation to a country like Nepal. Academia, research institutes can play a role as a responsible section of society at the moment.

\section{Conclusions / Recommendations / Future directions}

WHO along with other scientific communities are giving clear message that COVID-19 may not go, rather humans may need to live with it. A case, similar to that of AIDS, flu in recent past. Nepal, along with other sections of developing society, have to adopt accordingly. Even, scientific miracles happen, our access will be limited. Since, "Society is not a formula of mathematics, rather a complex phenomenon with multiple dimensions." Adapting Green Economy principles will be the only way to feed the population in first step. Recovering the collapsing economy secondly will also be managed by following Green economic products through proper management.

\section{Ethical approval}

Not required given the nature of the article.

\section{Funder information}

No funding.

\section{Competing interests}

None declared.

\section{References}

Bina O. The green economy and sustainable development: an uneasy balance?. Environment and Planning $\mathrm{C}$ : Government and Policy. 2013 Dec; 31(6):1023-47. https://journals.sagepub.com/home/epc

FAO. Nepal Forestry Outlook Study. Food and Agriculture Organization of United Nations, Asia and Pacific, Bangkok. 2009.Final Report Nepal's GHG Inventory for Third National Communication to the UNFCCC

GoN. Foreign Employment Information Management System (FEIMS), Report Ministry of Labour and Social Welfare, Government of Nepal, 2020.

GoN. Ministry of Forest and Environment. Government of Nepal, 2018. 
GoN. Sagarmatha Sambad Secretariat. Ministry of Foreign Affairs, Kath Government of Nepal, 2019.

Harari YN. The world after coronavirus. Financial Times. 2020 March 20. https://www.ft.com/content/19d903086858-11ea-a3c9-1fe6fedcca75.

IDS-Nepal, PAC and GCAP, 2014, Economic Impact Assessment of Climate Change in Key Sectors in Nepal July 2017 by Tribhuvan University, Central Department of Environmental Science.

Ministry of Forests and Environment. Forest Research and Training Centre (FRTC) Kathmandu, Nepal National Level Forests and Land Cover Analysis of Nepal using
Google Earth Images. Submitted to Third National Communication Project, Ministry of Population and Environment, Government of Nepal, Singh Durbar, Kathmandu, January 2019.

UNCTAD. Trade and Environment Review 2013: Wake Up Before It's Too Late. United Nations Conference on Trade and Development. 2013.

UNFCCC. Important Decisions of Conference of Parties of United Nation's Framework Convention on Climate Change, with annual updates. Nairobi work programme on Impacts, Vulnerability and Adaptation. 2006.

WHO. 2019, Novel Coronavirus. Strategic Preparedness and Response Plan. 2020. 